\title{
Smart Teaching and Learning with Big Data
}

\author{
Yijing $X U^{1, a}$ \\ ${ }^{1}$ General Education Center, Beijing Normal University Zhuhai Campus, China \\ a845443202@qq.com
}

Keywords: Big data, Smart education. Smart teaching. Smart learning.

\begin{abstract}
In this paper, it first introduces the major changes in contemporary education revolution today. What is the smart education, and the content of the smart education. And then tells the university teachers should be how to carry out the smart teaching, how to guide students to do smart learning. Finally, it also tells the truth about the current problems and difficulties, and the solution to these problems.
\end{abstract}

\section{Introduction}

From 2006 to 2010, the CPC Central Committee and the State Council formulated the national medium and long-term education reform and development plan (2010-2020) and other documents, This documents especially pointed out that the" information technology to the development of education has a revolutionary impact, we must attach its importance, and it is clear about the request to speed up the process of Informational education" [1] .

Informational education is a process of dynamic development. In the era of big data has come today, a huge educational reform has come. This will cause break the original traditional education and teaching mode, and the occurrence of earth shaking changes. It mainly reflected in: audio visual teaching, remote teaching, multimedia teaching, online teaching, network teaching, mobile network teaching, and self-organizing learning, blended learning, social learning, the massive open online course, micro-lecture and others kinds of courses, When these new ways and means in teaching, a new organizational form of teaching, new teaching facilities, new teaching resources, new teaching ideas, new running way and so on, are or will soon appear in front of us, we should be how to deal with and involved?

2012 Tsinghua University Press published Professor Xi Tao He edited "Smart Education" a Book [2], perhaps, it is the first book to introduce the smart education core content and concept.

After three years today, based on large data processing and data mining, the Smart Education meaning, already be following such a statement: the smart education is namely the informational education, it is in the field of Education (education management, education and teaching, education and scientific research) comprehensive in-depth use of modern information technology to facilitate the process of the reform and development of education. Its technical features are digital, networking, intelligent and multimedia, the basic feature is open, sharing, interaction, collaboration. It is to promote the modernization of education and information technology to change the traditional model [3].

\section{What is the "smart teaching" and "smart learning"}

The meaning of "Education Smart". The so-called wisdom education, is refers in the huge change of education, covering the smart teaching and smart learning, smart management, smart evaluate, wisdom for scientific research, smart services and other education application mode of the new generation of education system.

Which "smart teaching" and "smart learning" are two interdependent and inseparable the Interconnected whole, now the popular words, is namely "teaching reform". We face and should focus on "how to teach" and "how to learn" two areas. 
How to teach and how to learn effectively, the goal is the same, is to complete the task of learning, so the relationship is inseparable. but the two are different: the former is the work that the educator should do, the latter is the task that the educated student should accomplish.

The main way of "smart teaching" and "smart learning". Smart teaching included that audio visual teaching, remote teaching, multimedia teaching, online teaching, network teaching, mobile network teaching. Smart learning included that self-organizing learning, blended learning, social learning and so on.

Teacher's responsibility. In the face of new teaching methods and methods, new teaching organization form, new teaching resources, new teaching ideas, new ways of running schools, teachers' roles have been changed. These changes will be reflected in the overall process of teaching, the object of service is students, as "master"; teachers are as "waiter". Moreover, teachers must have the following capabilities: first, teachers should adapt to the modern teaching methods; followed by, teachers must be familiar with and master the modern teaching aid, and includes wireless communication tools, such as blog, twitter, e-mail, Wechat and so on; third, teachers must have more extensive knowledge and profound foundation of professional and academic level of higher; fourth, teachers should be in the ideological understanding, advancing with the times, to keep up with the pace of development of the times, correct understanding of this unprecedented education reform, and actively involved.

My view on teaching mode and curriculum model. Audio visual teaching method, more than 30 years ago in the Chinese colleges and universities have been widespread. The development of distance education is dependent on the development of Internet related technology, but also can be said that is one of the form of network teaching. Multimedia teaching is now widely used in the domestic universities, middle schools and primary schools, its history is as so as the development of distance education history, there are more than ten years. Online teaching, this teaching form is depend on the aforementioned various teaching methods generally carried out, has been very mature, in recent years to cause people's attention. Mobile network teaching is caused by the mobile classroom teaching mode, is a commonly known as mobile education. I believe that in the current teaching reform, in the realization of the wisdom learning has its unique role. Of course, in recent years, the introduction and application of micro course model, as one of the advantages of mobile network teaching. But as the MOOC curriculum model, I am not optimistic, it is almost before the existing daily teaching and teaching management been moved on the Internet only, and the production cost is high is staggering: recently, one university made one MOOC course spent $120000 \mathrm{RMB}$, if the University dozens or hundreds of courses are made the MOOC courses, its price (teaching effect and the input cost ratio) cannot be accepted.

My view on the learning way. For self-organizing learning, blended learning, social learning and a variety of learning methods, the effect is certainly some, but I think this just assistant way for the traditional classroom teaching, and can only be applied to certain types of courses, such as for the teaching of the general education course is certainly a very good effect, However, if it is used for engineering class courses, it may not be appropriate.

To achieve the best teaching effect of the teaching process. Teaching process, for each knowledge point, teachers should after the teaching, through a variety of feedback channels to understand students on learning content understanding and mastery, way of teaching adaptation degree and other requirements, and timely adjustment and correction of course teaching plan, teaching content, teaching way and method, in order to achieve optimal teaching effect. The overall teaching effect of the course is often come from all of the effect of each knowledge point. The above information feedback channels is come in addition to the traditional classroom questioning and classroom discussion, homework, should also include via the Internet and mobile communication tools, such as: e-mail, electronic conference, and blog, micro blog, Wechat and so on various ways.

The evaluation and basis of students learning effect. Students' mastery of the course content, of course, is one of the main basis for evaluating the effect of learning. However, we should pay more attention to students' autonomous learning ability and analysis problem and solving problem ability, 
students have independent thinking or insights, and whether there is "innovation ability" performance.

Science comprehensive evaluation for every students. Evaluation of college students, not just on the learning on scores, and depends on whether there are other skills and potential, students on academic activities and social activities participation, students' attitude to life and the value view of life, whether to have the basic morality and so on.

Student learning and some psychological dynamics changes, can be through their daily life traces, consumption, online dating, blog, micro blog, twitter, e-mail, Wechat and other semi structure data and non structure data for comprehensive analysis of related results were obtained.

Evaluation of educational achievement. The graduated rates, student employment rate, students employment destination direction, students after graduation stable work rate and so on, all of this can be from different aspects reflect the university educational achievements (effect).

\section{Current problems}

Implementation steps. As the leader of the education work and educators, must analyze the advantages and difficulties of the current work. And the current work must according with the processing as "overall planning, integration of resources, data sharing, focusing on the application of" principle, steadily, in order to achieve results.

To understand the relationship between general education and professional education. In the continuous development of modern science and technology today, it is not impossible that a personal become a proficient "generalist" or "all rounder" in various fields. In terms of natural law, human's natural life and energy are limited, and the refinement and development of social division of labor is the embodiment of social progress. Therefore, we promote forward both the inheriting Chinese traditional culture education and all the disciplines and various fields of professional education, all of them are not to be abandoned and must develop at same time. For more than ten years, with the development of the theory and practice of quality education in China, the relationship between general education and professional education is gradually recognized.

Correct understanding of what is the University General Education Curriculum. Now, in the university to carry out general education, has been widely recognized. Various colleges and universities have different experiences. Each school preselected course are more than hundred courses, if including the different content MOOC courses and open online courses, there are hundreds of courses. And its content can be said to cover the content of modern science and technology to primary even the primary and middle school education content. In the face of this "mixed content, structured chaos, different level" phenomenon [4], we should be to discuss the following questions: what are the training goal of higher education. The higher education is our main work, but "Science Popularization Education" and "Mass education", it's just our additional works. To reduce the level of higher education in the university is a great waste of social resources, but also is the fall back of modern education. Systematic and Standardized, that is making the quality and status of the course to be improved.

\section{Future work direction}

The cross and integration of information science and education science, it promote education reform and triggered today. The introduction and use of modern information technology to improve our teaching work, is the inevitable trend of education reform.

In order of developing our education science research, to cooperation with the teachers of information technology professional, this is one of the important ways, which will also become our a normal teaching work.

Through cooperation between colleges and universities, teaching and scientific research work, is the effective use of educational resources, improve the school's comprehensive strength, and to 
achieve rapid development and improvement of the only way.

\section{References}

[1] Information on http://edu.ifeng.com/news/detail_2010_07/30/1859314_2.shtml

[2] Information on http://item.jd.com/10914601.html

[3] Information on http://news.xinhuanet.com/info/2013-09/30/c_132764225.htm

[4] Guo Dacheng and Pang Haishao, 2015 College Quality Education Forum, Beijing Institute of Technology Press

[5] Guo Dacheng and Pang Haishao, 2013 College Quality Education Forum, Beijing Institute of Technology Press

[6] Guo Dacheng and Pang Haishao. 2012 College Quality Education Forum, Beijing Institute of Technology Press

[7] Guo Dacheng and Pang Haishao. 2011 College Quality Education Forum, Beijing Institute of Technology Press

[8] Information on http://phycjy.pinghu.gov.cn/readnews.asp?id=3121

[9] Information on http://baike.baidu.com/view/3496.htm

[10] Information on http://item.jd.com/10914601.html

[11] Information on http://baike.baidu.com/view/1316082.htm

[12] Inf Information on http://news.xinhuanet.com/info/2013-09/30/c_132764225.htm

[13] Information on http://baike.baidu.com/view/5478486.htm

[14] Information on http://baike.baidu.com/subview/6954399/13647476.htm

[15] Information on http://wenku.baidu.com/view/47dd86205901020207409c24.html 